\title{
Changes in Als2 Expression Leads to Different Outcomes on the Expression of Two NF-kB Targeted Genes in N2a and C2C12 Cell Lines
}

\author{
Als 2 Ekspresyonunun NF-kB Hedefli İki Gen Üzerindeki Olası Etkisinin \\ N2a ve C2C12 Hücre Hatlarında Araştırılması
}

\section{Mehmet OZANSOY ๑, Muzaffer Beyza OZANSOY ๑}

Ethics Committee Approval: Not Applicable.

Conflict of interest: The authors declare that they have no conflict of interest.

Funding: None.

Informed Consent: Not Applicable.
Cite as: Ozansoy M, Ozansoy MB. Als 2 Ekspresyonunun NF-kB Hedefli Iki Gen Üzerindeki Olası Etkisinin N2a ve $\mathrm{C} 2 \mathrm{C} 12$ Hücre Hatlarında Araștırılması. Medeniyet Med J. 2019;34:123-9.

\begin{abstract}
Objective: Amyotrophic Lateral Sclerosis (ALS) is a neurodegenerative disorder affecting spinal and cortical motor neurons. Motor neuron degeneration leads to progressive muscular atrophy. Als2 (alsin) is one of the causative genes of ALS and UXT gene is an interacting partner of Als2. Since UXT is a known cofactor in NF- $\kappa B$ enhancesome, we aimed here to compare the effects of Als2 silencing on NF-KB activity by using N2a and C2C12 cell lines.

Methods: Mouse neuroblastoma cells (N2a) and myoblast cell lines (C2C12) were used. Als2 was silenced by RNAi and UXT, A2O and IL8 expressions were measured by qRT-PCR. Data were statistically evaluated by Student $t$-test.

Results: A 73.4\% decrease was observed in Als2 expression in N2a cells, whereas $73.7 \%$ decrease in the C2C12 cells was found. UXT expression in Als2-silenced N2a cells was found to be decreased by $40 \%$, while a 9-fold increase in C2C12 cells was detected. IL8 expression demonstrated a $84 \%$ decrease in N2a cells. On the other hand,IL8 expression increased 50-fold in C2C12 cells. A2O expression increased by $65 \%$ in N2a cell line, and increased 10 fold in C2C12 cell line.

Conclusion: We have concluded that silencing Als2 gene over UXT on exerts different effects on $N F-\kappa B$ pathway We arrived at this conclusion because changes in the expressions of the IL8 and A2O genes differ in both cell lines. In addition, the link between Als2 and UXT is shown again in both cell lines and it is understood that the silencing Als2 may give rise to different results as for neuronal cells and muscle cells.
\end{abstract}

Keywords: ALS, Als2, NF-kB, N2a, C2C12

ÖZ

Amaç: Amiyotrofik Lateral Skleroz (ALS) spinal ve kortikal motor nöronları etkileyen nörodejeneratif bir hastalıktır. Motor nöron dejenerasyonu ise kaslarda ilerleyici atrofiye neden olur. ALS'ye neden olan genlerden biri Als2 (alsin) genidir ve UXT geni de Als2 ile etkilesimde olan genleden biridir. UXT proteininin NF-KB kompleksinde kofaktör olarak rol aldığı da bilinmektedir. Bu çalısmadaki amacımız, Als2'nin susturulmasının NF-KB aktivitesindeki olası etkilerini N2a ve C2C12 hücre hatlarında karșilaștırmaktır.

Yöntem: Bu çalışmada, fare nöroblastoma hücreleri (N2a) ile fare miyoblast hücreleri (C2C12) kullanıldı. Söz konusu hücrelerde Als2 geni RNAi ile susturuldu ve UXT, IL8 ve A2O genlerinin ekspresyonları qRT-PCR ile ölçüldü. Veriler Student t-test kullanılarak istatistiksel olarak değerlendirildi.

Bulgular: N2a hücrelerinde Als2 ekspresyonundaki azalış \%73,4 olurken C2C12 hücrelerinde $\% 73,7$ 'lik bir düsüs gözlendi. Als2 geni susturulmus N2a hücrelerinde UXT seviyesi \%40 azaIırken, C2C12 hücrelerinde 9 katlık bir UXT artışı saptandI. IL8 ekspresyonu N2a hücrelerinde \%84'lük bir düşüş gösterdi, ancak C2C12 hücrelerinde IL8 ekspresyonu 50 katık bir yükselişs kaydetti. Öte yandan A20 ekspresyonu N2a hücre hattında \%65 artarken, bu artıs C2C12 hücre hattında 10 misli olarak gerçekleşti.

Sonuç: Als2 geninin susturulmasının UXT üzerinden NF-кB yolağına olan etkilerinin farklı olduğu sonucuna ulassılmıștır. Bu sonuca IL8 ve A20 genlerinin ekspresyonlarındaki değișimlerin her iki hücre hattında da farklılık göstermesi üzerinden varılmıştır. Ayrıca Als2 ve UXT arasındaki bağlantı her iki hücre hattında da tekrar gösterilmiş ve Als2'nin susturulmasının nöronal hücreler ile kas hücreleri açısından farklı sonuçlar doğurabileceği de anlaşılmıștır.

Anahtar kelimeler: ALS, Als2, NF-kB, N2a, C2C12
Received: 07.02.2019

Accepted: 25.04 .2019

Online First: 10.06 .2019

Corresponding Author: M. Ozansoy

ORCID: 0000-0002-1079-8832 Istanbul Medipol University, International School of Medicine,

Department of Physiology, Istanbul, Turkey

mozansoy@medipol.edu.tr

M.B. Ozansoy ORCID: 0000-0003-4228-4577 Istanbul Medipol University, School of Medicine, Department of Physiology, Istanbul, Turkey 


\section{INTRODUCTION}

Amyotrophic Lateral Sclerosis (ALS) is a neurodegenerative condition leading to motor neuron loss. Degeneration of motor neurons causes progressive wasting of skeletal muscles and muscular atrophy, and death ensues within 2-5 years of diagnosis. Ten per cent of the ALS cases have hereditary transmission and the rest is sporadic ${ }^{1}$. One of the proposed pathological mechanisms underlying ALS pathogenesis is the "dying back" phenomenon, which emphasizes that the cell death starts from the neuromuscular junction, spreads along the axon and eventually arrives at the neuronal cell body ${ }^{2,3}$. This hypothesis is mainly based on the assumption that neuropathological changes are caused by the alterations of the neuromuscular junction, which in turn, are induced by the pathological changes of the muscle. Recent studies about the "dying back" phenomenon have indicated that during the early stages of the ALS pathogenesis in Sod1(G93A) transgenic mice nerve terminals and neuromuscular junctions are found to be degraded while the soma of the motor neurons located in the spinal cord gray matter remain intact. In addition, impaired mitophagy has been described in the neuromuscular junctions of the Sod1(G93A) transgenic mice implying the possible role of mitochondrial involvement in these very special subcellular regions ${ }^{4,5}$.

In addition to this hypothesis, excitotoxicity, oxidative stress, abnormal energy metabolism, dysfunction of axonal transport and inflammation have also been proposed as candidate mechanisms for the degeneration of motor neurons ${ }^{6}$.

ALS2 (alsin), one of the causative genes of ALS, is located on chromosome 2q33.1. Mutations of ALS2 leading to a premature termination of translation or to amino acid substitution, cause an autosomal recessive type of ALS with juvenile onset through the loss of function of the alsin protein. The alsin protein contains several functional domains including three putative Guanine Nucleoti- de Exchange Factor (GEF) domains, the regulator of chromosome condensation 1 (RCC1) domain, the Dbl-homology/Pleckstrin-homology (DH/PH) domain and the Vacuolar Protein Sorting 9 (VPS9) domain ${ }^{7,8}$.

Recent scientific literature exhibits that the alsin protein may play a role in endosomal trafficking and that it could also function in intracellular signalling with its $\mathrm{DH} / \mathrm{PH}$ domain? . The possible neuroprotective function of alsin has also been proposed in degenerating motor neurons in which mutant SOD1 is expressed ${ }^{10-12}$.

Our group has already found that the Ubiquitously Expressed Transcript gene $(U x t)$ is an interacting partner of $A / s 2^{13,14}$ and it is known that the UXT protein is a chaperon belonging to $\alpha$-class prefoldin-like family proteins ${ }^{15}$. This interaction has also been documented in primary spinal motor neurons and the interaction has an effect on the two NF-кB-dependent genes (IL8 and A20) through $U x t^{16}$.

As a complementary study we here generated Als2 knock-down stable cell lines of neuronal N2a and myoblast $\mathrm{C} 2 \mathrm{C} 12$ cells and aimed to investigate the changes in the expression levels of $U x t$ and NF- $\kappa \mathrm{B}$ activated genes, IL8 and A20.

\section{MATERIALS and METHODS}

\section{Plasmid constructs}

The full open reading frame of the mouse Als2 transcript was amplified by using the following primers:

Als2(FL)F: 5'GGACTCAAAGAAGAAAAGCTCAA CAGA 3'

Als2(FL) R: 5' TTACAACCAAAATAGCACAAAAGTCCA 3'

The PCR product of the full length Als2 was cloned first into the PTZR57R/T vector by using "InsTAclone PCR Cloning Kit” (Fermentas, Canada) and then transferred to the mammalian expressi- 
on vector pCRUZ-GFP'M (Santa Cruz, USA), using EcoRI and Smal sites.

In order to generate short hairpin RNA (shRNA) specific for the $\mathrm{DH} / \mathrm{PH}$ region of the Als2 transcript, we used the pSilencer ${ }^{\mathrm{TM}} 2.1$-U6 (Ambion, ABI, USA) vector. The following oligos were annealed and cloned into the vector according to the manufacturer's instructions.

Als2(KD)F: 5'GATCCATGACGGATTCCTTGAGGAT TCAAGAGATCCTCAAGGAATCCGTCATTTTTTTGG AAA 3'

Als2(KD)R: 5'AGCTTTTCCAAAAAAATGACGGAT TCCTTGAGGATCTCTTGAATCCTCAAGGAATCCGT CATG 3'

\section{Cell Culture Assays}

Neuronal N2a cells were purchased from ATCC (USA) (Catalog no: CCL-131). They were grown and propagated in Minimal Essential Medium (MEM) (GIBCO, USA) containing 10\% (v/v) Foetal Bovine Serum (GIBCO, USA), $200 \mathrm{mM}$ Glutamine (GIBCO, USA), 1\% (v/v) Non-Essential Amino

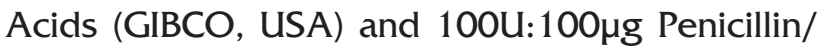
Streptomycin cocktail (GIBCO, USA) in a cell culture incubator. The $\mathrm{C} 2 \mathrm{C} 12$ cell line was also purchased from ATCC (USA) (Catalog no: CRL-1772), and it was propagated in Dulbecco's Modified Eagle's Medium (DMEM) (GIBCO, USA), containing 10\% (v/v) Foetal Bovine Serum (GIBCO, USA), $200 \mathrm{mM}$ Glutamine (GIBCO, USA), 1\% (v/v) Non-Essential Amino Acids (GIBCO, USA) and $100 \mathrm{U}: 100 \mu \mathrm{g}$ Penicillin/Streptomycin cocktail (GIBCO, USA). Because the Als2 knock-down expression plasmids contain hygromycin- resistance gene for selection, the optimum hygromycin (Sigma, USA) concentration was determined as 600 $\mu \mathrm{g} / \mathrm{ml}$ by using the antibiotic titration method for both cell lines. Then neuronal N2a and myoblast C2C12 cells were grown until $60 \%$ confluency was reached, and they were stably transfected with 2 $\mu \mathrm{g}$ expression vector $\mathrm{pSilencer}{ }^{\mathrm{TM}}$ 2.1-U6 (Ambion, ABI, USA), containing shRNA, specific for the Als2 transcript or control vector having scrambled
shRNA sequence provided by the manufacturer in OPTIMEM (GIBCO, USA) and FuGENE HD Transfection Reagent (Roche, Germany), according to the manufacturer's instructions. After 72 hours of transfection, OPTIMEM was replaced with complete growth medium and $600 \mu \mathrm{g} / \mathrm{ml}$ hygromycin was added to the medium every three days for antibiotic selection of stably transfected cells. At the end of day 10 of hygromycin selection, the Als2 gene expression was measured.

In order to overexpress Als2 transiently in both cell types, pCRUZ-GFP ${ }^{\mathrm{TM}}$ (Santa Cruz, USA), the mammalian expression vector containing Als2 open reading frame was used and the recommended transfection protocol of FuGENE HD Transfection Reagent (Roche, Germany) was followed.

\section{Quantitative RT-PCR ( $q R T-P C R)$}

In order to determine the expression levels of Als2, Uxt, IL8 and A20, total RNA was isolated from the cells by using the High Pure RNA Isolation Kit (Roche, Germany). QRT-PCR was performed using the LightCycler RNA Master SYBR Green I Kit and LightCycler 2.0 (Roche, Germany). The following primers were used:

Als2F: 5' TCCAGTTCTTGCTATGAGTCTCT 3' Als2R: 5' GGAATCCGTCATTTTCCCAGG 3' UxtF: 5' TTGGGCTGTAACTTCTTCGTTG 3' UxtR: 5' AGGAGAGAACTCTTTCGGTCAA 3' IL8F: 5' ATGCCCTCTATTCTGCCAGAT 3'

\section{IL8R: 5' GTGCTCCGGTTGTATAAGATGAC 3'}

A2OF: 5' TGGGTGCCCTTTTACTTTGAAT 3' A2OR: 5' GCTCTGCTGTAGTCCTTTTGAAA 3' $\beta$-ActinF: 5' GGCTGTATTCCCCTCCATCG 3' $\beta$-ActinR: 5' CCAGTTGGTAACAATGCCATGT 3'

QRT-PCR experiments were repeated at least three times independently and the $\beta$-Actin transcript level was used to normalize the data according to $\Delta \Delta C q$ method. Student-t test in the Statistical Package of Social Sciences (SPSS) Version 22 software was used to measure the statistical significance of the fold changes seen in the data. When 
the $p$ value was found to be less than 0.05 , the fold changes were considered statistically significant. To test the normality of the data, AndersonDarling (AD) test was implemented. In order to implement the normality test AD-Test Calculator developed by the University of Missouri, was used as a free excel-based software ${ }^{17}$. When the $p$ value was found to be greater than 0.05 , then it was considered that the normality of the data was attained.

\section{RESULTS}

Alterations of Uxt Expression when Als2 expression was changed

After neuronal $\mathrm{N} 2 \mathrm{a}$ and $\mathrm{C} 2 \mathrm{C} 12$ myoblast cells were stably transfected with pSilencer $^{\mathrm{TM}} \mathrm{2}$.1-U6 (Ambion, $\mathrm{ABI}, \mathrm{USA}$ ), containing shRNA specific for the $\mathrm{DH} / \mathrm{PH}$ region of the Als2 transcript, total RNA isolation was performed; and followed by qRT-PCR in order to check the Als2 transcript levels. In neuronal N2a cells, a significant (73.4\%) decrease in Als2 transcript was observed with respect to the control cells $(p<0.0001)$, whereas a a statistically significant reduction of $73.7 \%$ was found in in the $\mathrm{C} 2 \mathrm{C} 12$ myoblast cells $(p<0.0001)$ (Fig. 1a and b). In both cell lines Uxt expression was measured using the same method. In Als2 knock-down background of neuronal N2a cells, Uxt expression was found to be significantly dec-

a

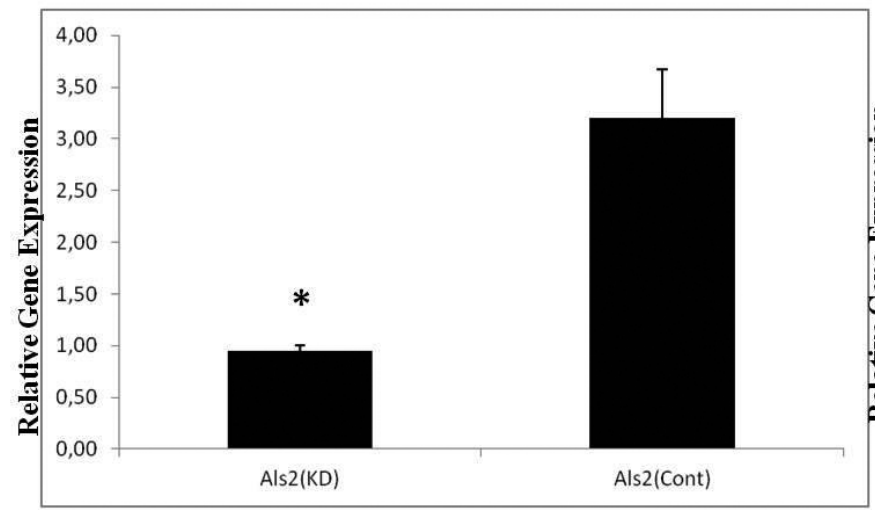

reased by $40 \%$ ( $p<0.0001)$, while in Als2 knockdown $\mathrm{C} 2 \mathrm{C} 12$ myoblasts Uxt expression increased 9-fold ( $p<0.0001$ ) (Fig.2a and $b$ ).

We also performed experiments of Als2 overexpression in both cell lines to check if the Uxt expression changed. It was found that when Als2 was overexpressed transiently in both neuronal $\mathrm{N} 2 \mathrm{a}$ and C2C12 myoblasts, UXT expression was statistically significantly upregulated $(p<0.0001$ (Fig. 2c and d).

\subsection{Changes of the Expression of NF- $\kappa B$ activated} genes when Als2 was downregulated

Knowing that the $U x t$ has a role in the activity of NF- $\mathrm{KB}$ activated genes such as IL8 and A20, these two genes have been chosen to elucidate the possible effect of $A / s 2$ silencing on the NF- $\kappa B$ pathway through the alterations of Uxt expression. In Als2 knocked-down neuronal N2a cells, IL8 expression was found to be decreased significantly by $84 \%(p<0.0001)$, on the other hand, in Als2 knocked-down C2C12 myoblasts, it significantly increased by approximately 50 -fold $(p<0.0001)$ (Fig. 3a and b). A20 expression was found to be upregulated by only $65 \%(p<0.0001)$ in $A / s 2$ knocked-down neuronal N2a cells, whereas it was drastically increased (10-fold) in Als2 knocked-down C2C12 myoblasts ( $\mathrm{p}<0.0001)$ (Fig. $3 c$ and $d)$. b

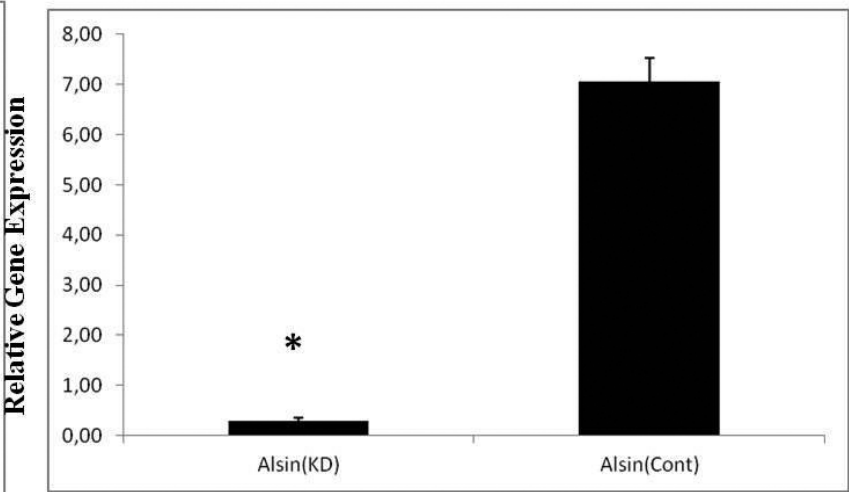

Figure 1. Effect of Als2 silencing on Uxt expression in neuronal N2a (a) and C2C12 myoblast cell lines (b). (*) symbol indicates that $p<0.0001$ and bars indicate standard deviations (SD). 
M. Ozansoy et al. Changes in Als2 Expression Leads to Different Outcomes on the Expression of Two NF-kB Targeted Genes in N2a and C2C12 Cell Lines

a

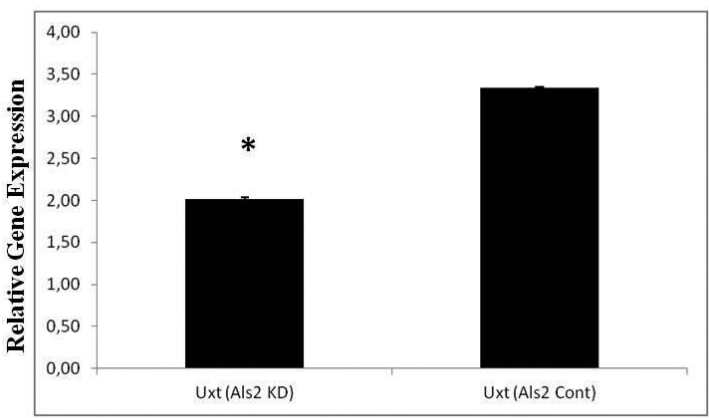

C

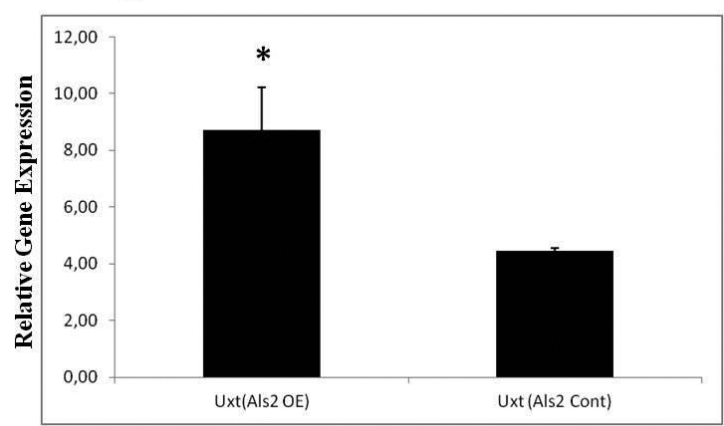

b

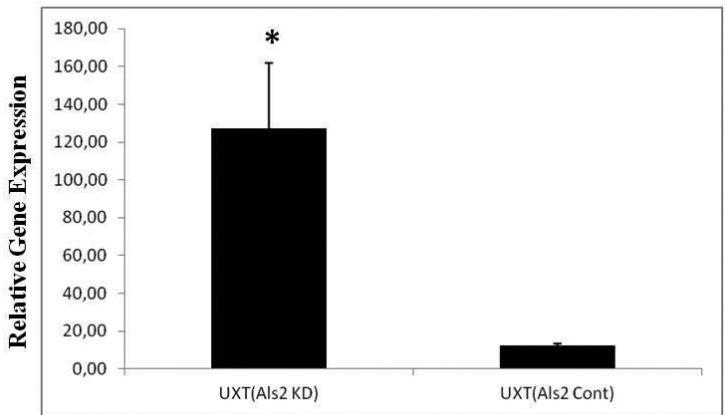

d

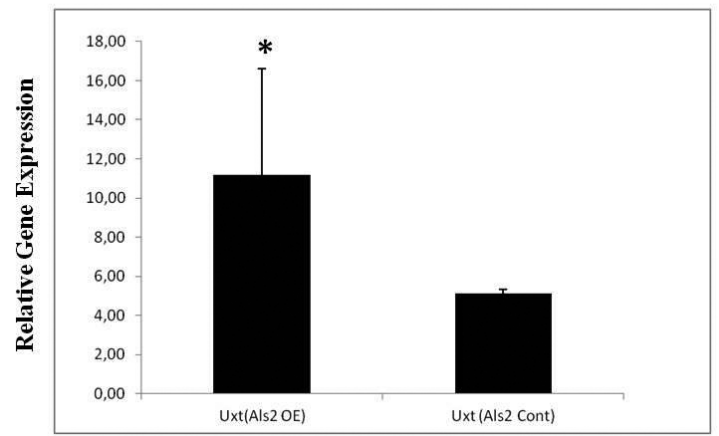

Figure 2. Effect of Als2 silencing on Uxt expression in N2a cells (a) and in C2C12 myoblasts (b). Effect of Als2 overexpression on Uxt expression in $\mathrm{N} 2 a$ cells $(\mathrm{c})$ and in $\mathrm{C} 2 \mathrm{C} 12$ myoblasts (d). $\left(^{*}\right)$ symbol indicates that p $<0.0001$ and bars indicate standard deviations (SD).

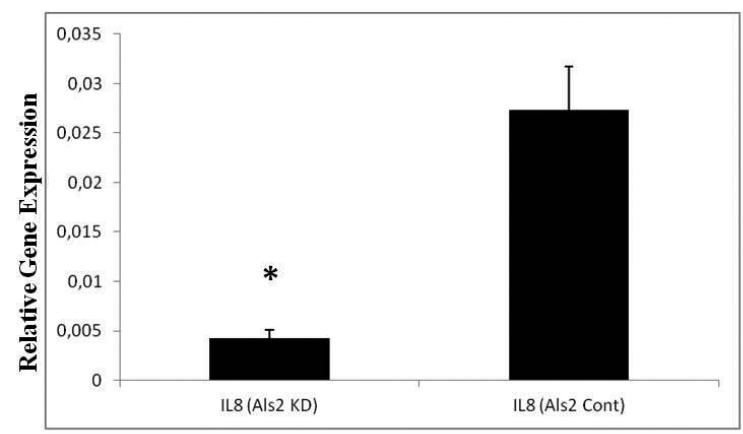

C

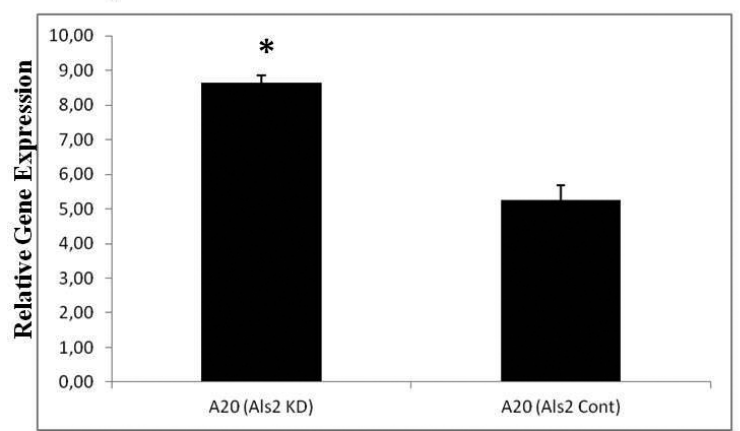

b

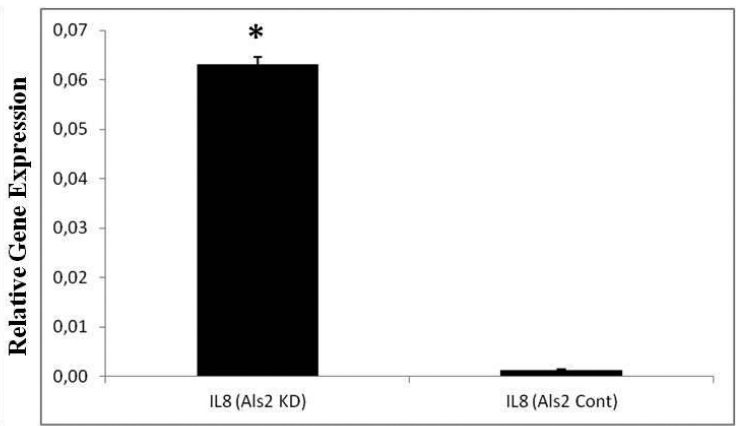

d

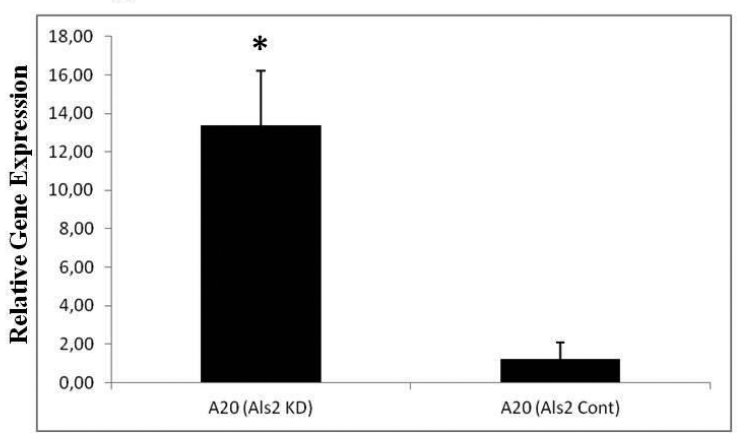

Figure 3. Effect of Als2 silencing on IL8 expression in N2a cells (a) and in C2C12 myoblasts (b). Effect of Als2 silencing A20 expression in N2a cells (c) and in $\mathrm{C2C12}$ myoblasts (d). ( $\left.{ }^{*}\right)$ symbol indicates that $p<0.0001$ and bars indicate standard deviations (SD). 


\section{DISCUSSION}

Although a set of genes responsible for the development of ALS, when mutated, has been described so far, the underlying molecular mechanisms remain to be elucidated. The critical fact concerning ALS pathology is that the degenerative process occurring in motor neurons starts at the neuromuscular junction; this phenomenon (dying-back) leads some researchers to consider that not only motor neurons but also the muscles which these motor neurons innervate should also be taken into account ${ }^{18}$.

$A L S 2$, one of the causative genes of ALS, encodes a protein, which has several functional domains, still the exact function of the ALS2 protein is not well understood. Knowing that the Als2 protein interacts with UXT, and UXT is a cofactor in NF- $\kappa B$ enhancesome complex, in this study we aimed to search for the possible effects of Als2 gene silencing on NF- $\mathrm{kB}$ activity. The gene expression analyses above reveal that neuronal N2a cells and $\mathrm{C} 2 \mathrm{C} 12$ myoblasts respond differently to Als2 knock-down in terms of UXT gene expression. These responses were followed by investigating the expression levels of IL8, and $A 20$.

Although A20 expression was found to be upregulated in both cell lines used in this study; the amount of this increase was quite different. In N2a cells $A 20$ was upregulated at a rate of $65 \%$, on the other hand, in $\mathrm{C} 2 \mathrm{C} 12$ cell line it was upregulated 10 -fold. Knowing that $A 20$ has a regulatory activity on NF-KB activity and apoptotic responses, this difference may be linked to the notion that the pro-apoptotic cellular events would be boosted in myoblasts when Als2 is silenced, while the A20-related pro-apoptotic activation is moderate in N2a cells ${ }^{19-21}$. The behaviour of the IL8 expression is totally different. In N2a cell line it is downregulated in the Als2 knock-down background, however, in C2C12 cells IL8 expression increases very dramatically.
These findings show that not only the Als2 protein interacts with Uxt as it was previously shown ${ }^{13}$, but also the Als2 gene expression affects the Uxt gene expression both in N2a cells and $\mathrm{C} 2 \mathrm{C} 12$ myoblasts.

From the perspective of the "dying back phenomenon" our findings indicate that the inflammatory alterations would start at the muscle tissue and the degenerative changes may spread from the muscle to the motor neuron via neuromuscular junction ${ }^{22,23}$. Also in both our Als2 silenced cell lines pro-apoptotic gene expression was represented by increases in $A 20$ gene expression but in myoblasts it increased dramatically, which would lead us to consider that the initiation of apoptotic events may also start from the muscle.

Altogether these results imply that inflammatory and pro-apoptotic alterations could both be present in motor neurons and skeletal muscles, but in order to reach more definitive conclusions about the starting site of degenerative processes seen in ALS, co-culturing studies of neuronal and skeletal muscle cell lines will be implemented, or co-culturing of primary spinal motor neurons with primary skeletal muscle cells will be performed $^{24-27}$.

\section{CONCLUSION}

In these cell lines, responses to Als2 knock-down in terms of UXT gene expression were different. These responses were followed by investigating the expression levels of IL8, and A20. Our findings show that not only the Als2 protein interacts with UXT, but the Als2 gene expression affects the UXT gene expression both in N2a cells and $\mathrm{C} 2 \mathrm{C} 12$ myoblasts.

\section{REFERENCES}

1. Ticozzi N, Tiloca C, Morelli C, et al. Genetics of familial Amyotrophic lateral sclerosis. Arch Ital Biol. 201 1;149:6582. [CrossRef]

2. Boillee S, Velde CV, Cleveland DW. ALS: A Disease of 
motor neurons and their nonneuronal neighbors. Neuron. 2006;52:39-59. [CrossRef]

3. Dion PA, Daoud H, Rouleau GA. Genetics of motor neuron disorders: New insights into pathogenic mechanisms. Nat Rev Genet. 2009;10:769-82. [CrossRef]

4. Dadon-Nachum M, Melamed E, Offen D. The "dyingback" phenomenon of motor neurons in ALS. J Mol Neurosci. 2011;43:470-7. [CrossRef]

5. Rogers RS, Tungtur S, Tanaka T, et al. Impaired mitophagy plays a role in denervation of neuromuscular junctions in ALS mice. Front Neurosci. 2017;11:473-90. [CrossRef]

6. Rothstein JD. Current hypotheses for the underlying biology of amyotrophic lateral sclerosis. Ann Neurol. 2009;65(Suppl. 1):S3-S9. [CrossRef]

7. Yang $Y$, Hentati A, Deng $H X$, et al. The gene encoding alsin a protein with three guanine-nucleotide exchange factor domains is mutated in a form of recessive amyotrophic lateral sclerosis. Nat Genet. 2001;29:160-5. [CrossRef]

8. Hadano S, R. Kunita, A. Otomo, K. Suzuki-Utsunomiya $\mathrm{K}$, Ikeda JE. Molecular and cellular function of ALS2/alsin: implication of membrane dynamics in neuronal development and degeneration. Neurochem Int. 2007;51:74-84. [CrossRef]

9. Chandran J, Ding J, Cai H. Alsin and the molecular pathways of amyotrophic lateral sclerosis. Mol Neurobiol. 2007;36:224-31. [CrossRef]

10. Hadano S, Otomo A, Kunita R, et al. Loss of ALS2/alsin exacerbates motor dysfunction in a SOD1H46Rexpressing mouse ALS model by disturbing endolysosomal trafficking. PLoSOne. 2010;5:1-20. [CrossRef]

11. Lai C, Xie C, Shim H, Chandran J, Howell BW, Cai H. Regulation of endosomal motility and degradation by amyotrophic lateral sclerosis 2/Alsin. Mol Brain. 2009;2:23. [CrossRef]

12. Cai H, Shim H, Lai C, et al. ALS2/Alsin knockout mice and motor neuron diseases. Neurodegen Dis. 2008;5:35966. [CrossRef]

13. Enunlu I, Ozansoy M, Başak AN. Alfa-class prefoldin protein UXT is a novel interacting partner of amyotrophic lateral sclerosis 2 (Als2) protein. Biochem Biophys Res Commun. 2011;413:471-5. [CrossRef]

14. Çetin-Ozansoy MB, Ozansoy M. Als2 silencing affects the expression of two NF- $\kappa \mathrm{B}$ targeted genes via UXT in adult mouse primary spinal motor neuron culture. Medeniyet Med J. 2018;33:227-34. [CrossRef]
15. Schröer A, Schneider S, Ropers HH, Nothwang HG. Cloning and characterization of UXT, a novel gene in human $\mathrm{Xp} 11$, which is widely and abundantly expressed in tumor tissue. Genomics. 1999;56:340-3. [CrossRef]

16. Sun S, Tang Y, Lou X, et al. UXT is a novel and essential cofactor in the NF-kappaB transcriptional enhanceosome. J Cell Biol. 2007;178:231-44. [CrossRef]

17. AD-Test Calculator developed by the University of Missouri https://www.statisticshowto.datasciencecentral. com/anderson-darling-test/ (Access Date: 25/01/2019)

18. Dupuis L, Loeffler JP. Neuromuscular junction destruction during amyotrophic lateral sclerosis: Insights from transgenic models. Curr Opin Pharmacol. 2009;9:341-6. [CrossRef]

19. Coornaert B, Carpentier I, Beyaert R. A20: Central Gatekeeper in Inflammation and Immunity. J Biol Chem. 2009;284:8217-21. [CrossRef]

20. Beyaert R, Heyninck K, Van Huffel S. A20 and A20binding proteins as cellular inhibitors of nuclear factor$\kappa \mathrm{B}$-dependent gene expression and apoptosis. Biochem Pharmacol. 2000;60:1143-51. [CrossRef]

21. Shembade N, Parvatiyar K, Harhaj NS, Harhaj EW. The ubiquitin-editing enzyme A20 requires RNF11 to downregulate NF- $\mathrm{B}$ signalling. EMBO J. 2009;28:513-22. [CrossRef]

22. Rocha MC, Pousinha PA, Correia AM, Sebastiao AM, Riberio JA. Early changes of neuromuscular transmission in the SOD1(G93A) mice model of ALS start long before motor symptoms onset. PLoS One. 2013;8:1-11. [CrossRef]

23. Fogarty MJ. Driven to decay: Excitability and synaptic abnormalities in amyotrophic lateral sclerosis. Brain Res Bull. 2018;140:318-33. [CrossRef]

24. Li Q, Spencer NY, Pantazis NJ, Engelhardt JF. Alsin and SOD1G93A Regulate Endosomal ROS Production by Glial Cells and Pro-Inflammatory Pathways Responsible for Neurotoxicity. J Biol Chem. 2011;286:40151-62. [CrossRef]

25. Kaltschmidt B, Kaltschmidt C. NF-kappaB in the nervous system. Cold Spring Harb Perspect Biol. 2009; 1:a001271. [CrossRef]

26. Wan F, Lenardo MJ. The Nuclear Signaling of NF-кB: Current Knowledge, New Insights and Future Perspectives. Cell Research. 2010;20:24-33. [CrossRef]

27. Kjaelgaard AL, Pilely K, Olsen KS, et al. Amyotrophic lateral sclerosis: The complement and inflammatory hypothesis. Mol Immunol. 2018;102:14-25. [CrossRef] 